UDC 621.318 .001 .4

\title{
TOPOLOGICAL TRANSIENT MODELS OF THREE-PHASE FIVE-LIMB TRANSFORMER
}
ZIRKA S. E.
Professor of the Department of Physics and Technology of the Dnipro National University, Dnipro, Ukraine,e-mail: zirka@email.dp.ua;
MOROZ Y. I.
Ph.D., Associate professor of the Department of Physics and Technology of the Dnipro National University, Dnipro, Ukraine, e-mail: yuriy_moroz@i.ua;
ARTURI C. M. Professor of the Department of Electronics, Information and Bioengineering of the Politechnico di Milano, Milan, Italy, e-mail: cesaremario.arturi@polimi.it;
BONNMAN D. Ph.D., ABB AG, Bad Honnef, Germany, e-mail: dietrich.bonmann@de.abb.com.

Purpose. To show capabilities of topological models of three-phase, five-limb transformer to correctly represent transformer operation in regimes with high flux densities in the core. As a practically important example, time domain response of transformer subjected to geomagnetically induced currents (GIC) is analyzed and compared with results of a comprehensive field experiment.

Methodology. Transformer magnetic model, which takes into account geometry of the core and windings, is transformed in a dual electric equivalent scheme, whose transient is calculated by using EMTP-ATP. The results obtained demonstrate the importance of incorporating the positive and zero sequence impedances of power network.

Findings. A simple and reliable model of five-limb transformer is proposed. It was found that the presence of the transformer tank can be effectively accounted for by linear inductances representing the paths of the off-core fluxes from yoke to yoke. The modeling of GIC events represented in the paper is the most accurate ever obtained for threephase, five-leg transformers. The model is validated by close agreement of the predicted values and waveforms of the phase currents and reactive power with those measured in tests performed on two 400 MVA transformers connected back-to-back and to a $400 \mathrm{kV}$ power network.

Originality. It is shown that a simplified non-hysteresis model developed portrays the behavior of the of five-limb transformer under GIC condition with the same good accuracy as its hysteresis model. Both the transformer models are well grounded. So, the paper dispels some misconceptions about the influence of the hysteresis properties of the core material and tank in transient modeling of five-leg transformers.

Practical value. The practical value and significance of the paper is caused by the fact that the model proposed is a simple and reliable tool for power system studies. The paper warns of using unnecessary complicated models whose parameters are difficult to be estimated by experiments or calculations.

Key words: five-limb transformer, topological transient models, transients, off-core magnetic fluxes, current waveforms, reactive power, experimental validation, back-to-back transformer test.

\section{INTRODUCTION}

Over the last decades, a common practice in transient modeling of large power transformers is the use of their topological models [1] - [6]. The advantage of these low-frequency models is their ability to reproduce individually dynamic processes in the core limbs and yokes, as well as the off-core magnetic fluxes outside the windings. The latter feature becomes especially important when the core approaches saturation and some part of the flux leaves the core and closes through the air (oil) and transformer tank. The role of the off-core fluxes and thus the necessity for a detailed tank model is different for different transformer constructions. The off-core flux is significant in three-limb three-phase transformers, so a transient model of the tank was proposed in [4]. The lesser role of the tank in five-limb transformers is caused by the presence of the end (lateral) core limbs providing the paths for the unbalanced (zero-sequence) flux.

Perhaps the first topological model of the five-limb transformer, which covers the range of high flux densities, was proposed in [1], in which a discussion was raised concerning the necessity to model transformer tank. Because of the lack of experimental data, the "tank problem" for large transformers remained open up to now, although systematic measurements on five-leg transformers with saturated cores were reported in 2002 [7]. These measurements were carried out on two 400 MVA units connected back-to-back and to the Fingrid power network to simulate conditions experienced by transformers in the presence of geomagnetically-induced currents (GIC). The distinguishing feature of the work described in [7], is a large (up to $200 \mathrm{~A}$ ) DC current injected in the transformers' neutrals and a considerable reactive power (55 Mvar) consumed by each of the transformers in this extreme regime.

Although the mentioning of the comprehensive experiment in [7] has become customary in the literature, there was no successful attempt to reproduce it with a model. An effort to repeat experimental results of [7] has been recently undertaken in [8]. However it will be shown in Section V that the outwardly plausible results represented in [8] were obtained due to deviations from the actual experimental conditions and hence cannot validate the "advanced" model [9], [10].

The aim of the present paper is to show that the measurements in [7] can be portrayed accurately by topological models developed in the framework of the conven- 
tional approach [1]-[5] if the network impedances are taken into account.

\section{II.THE BACK-TO-BACK TRANSFORMER TEST}

The experimental setup in fig. 1 consists of two similar YNyn0d11 400/400/125 MVA full transformers, T1 and $\mathrm{T} 2$, with rated voltages $410 / 120 / 21 \mathrm{kV}$. The mediumvoltage (MV) $120-\mathrm{kV}$ windings are nearest to the core, the high-voltage (HV) 410-kV windings are in the middle, and the outermost are the low-voltage (LV) $21-\mathrm{kV}$ deltaconnected windings. The turn numbers $N_{\mathrm{M}}, N_{\mathrm{H}}$, and $N_{\mathrm{L}}$ in these windings of $\mathrm{T} 2$ are 224, 766, and 68.

The welding generator $\mathrm{G}$ serves to inject the dc biasing current $I_{\mathrm{dc}}$ into the HV neutrals of both T1 and T2, thus providing the DC currents $I_{\mathrm{dc}} / 3$ in each of the $\mathrm{HV}$ windings.

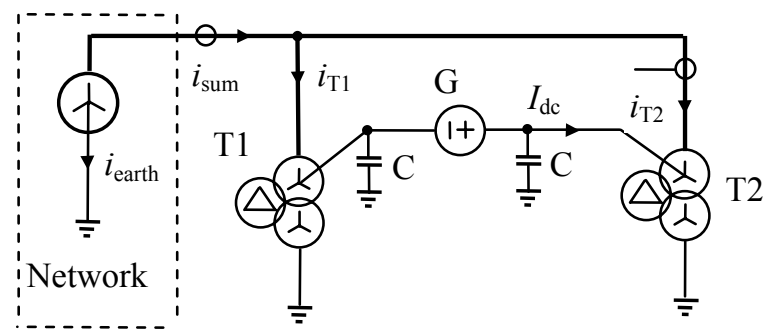

Figure 1. Experimental setup in [7].

Important elements of both the experimental setup and the corresponding model are shunt capacitors $C$, which form the $\mathrm{AC}$ earthing of the transformers and isolate the generator $\mathrm{G}$ from earth. Two current transformers are to monitor the variables designated in fig. 1. A summary of other transformer data and measurements can be found in [7].

\section{TOPOLOGICAL TRANSFORMER MODEL}

It was already noted in the literature that a lot of topological models exist for a given transformer configuration [11]. Some of them are unnecessary complicated and contain parameters difficult to be estimated by experiments or calculations. An example is the division of the yokes into sections [9], [11]; another one is the planar model in which the cover and bottom of the tank are represented by one-dimensional elements that results in the "tank", which consists of only the left and right walls [8]. As explained in [12], questionable is also the lumped character of the tank elements, and that each wound leg of the core has its own "tank" [10].

The tractable model employed in this paper is based on the magnetic circuit in fig. 2, which is a development of that described in [5]. To save space, only the elements related to the leg A are mainly shown in fig. 2. In particular, the sources of magnetomotive force (MMF) $F_{\mathrm{M}}, F_{\mathrm{H}}$, and $F_{\mathrm{L}}$ represent the MV, HV, and LV windings. The magnetic flux paths in the core are shown as solid rectangles, which represent the legs (elements $R_{\mathrm{a}}, R_{\mathrm{b}}, R_{\mathrm{c}}$ ), yokes ( $R_{\mathrm{ab}}$ and $R_{\mathrm{bc}}$ ) and the end limbs $\left(R_{\mathrm{d}}\right.$ and $\left.R_{\mathrm{f}}\right)$. The innermost channel Leg-MV and the equivalent leakage channels
MV-HV and HV-LV are characterized by the linear reluctances $R_{01}, R_{12}$, and $R_{23}$ respectively. The negative (fictitious) reluctances $R_{\mathrm{p}}$ are added to match all three binary short-circuit inductances [2].

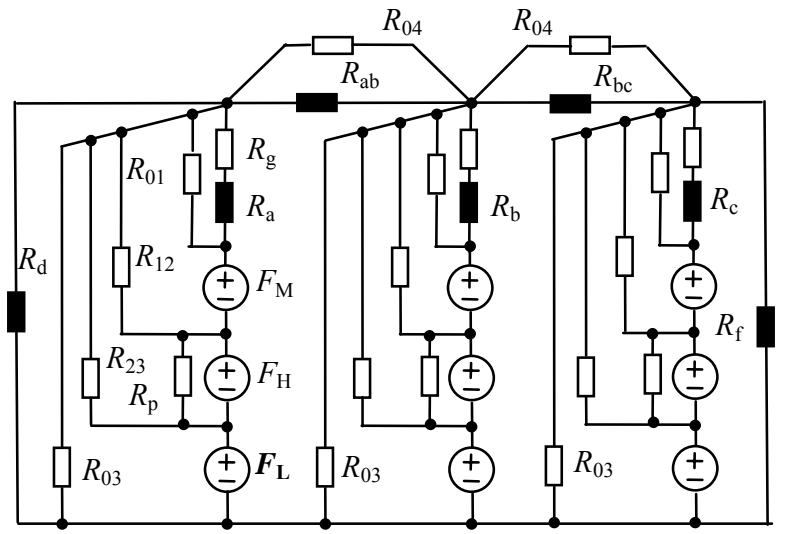

Figure 2. Magnetic (reluctive) transformer model.

Linear reluctances $R_{03}$ represent the flux paths from yoke to yoke, which are outside the windings. Reluctances $R_{04}$ are for fringing flux paths in parallel to the yokes. Reluctances $R_{\mathrm{g}}=g /\left(\mu_{0} S_{\mathrm{leg}}\right)$ take into account the air gaps $g$ at the core joints, which are related to the legs with cross-section $S_{\text {leg. }}$.

The electrical (duality-derived) equivalent of the model is shown in fig. 3 between the nine ideal transformers (ITs). The linear inductances $L$ in fig. 3 are indexed with the same symbols as the linear reluctances $R$ in fig. 2, and $L=N_{\mathrm{H}}^{2} / R$. The seven hysteretic elements are the ATPDraw implementations of the dynamic hysteresis model (DHM) [13]. The 1:1 turn ratio of three ITs at $\mathrm{HV}$ terminals points out that the model parameters are referred to $N_{\mathrm{H}}$ turns. So, the turn ratios $n$ of the ITs at MV and LV terminals are $N_{\mathrm{M}} / N_{\mathrm{H}}$ and $N_{\mathrm{H}} / N_{\mathrm{L}}$ respectively.

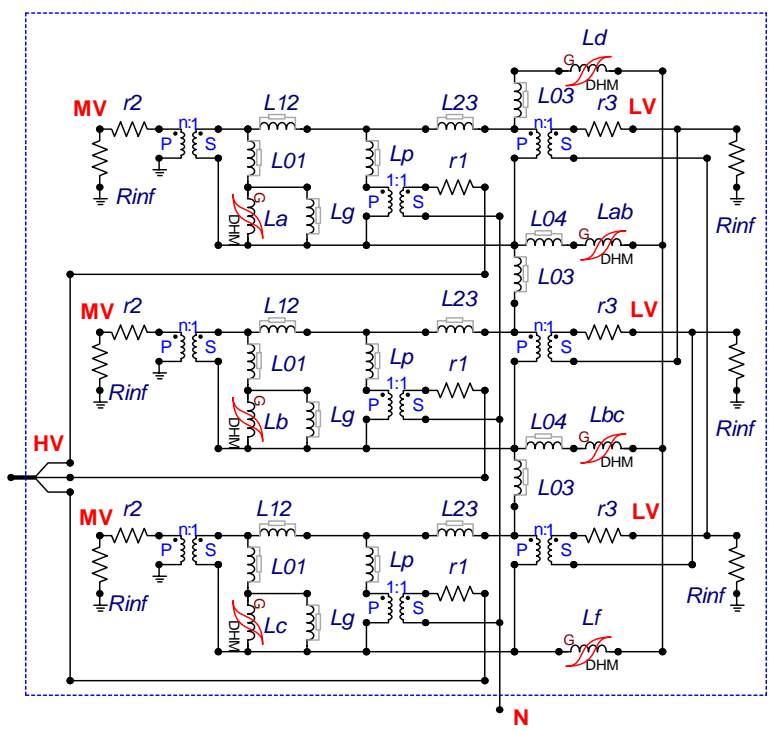

Figure 3. Electric transformer model.

As in many practical cases, it was not possible to determine the material of the core, so it was first assumed 
that the cores of both transformers are assembled from grain-oriented steel 27ZDKH85. Then it was observed that the same results (the ones presented in the paper) are obtained when using AK steel $\mathrm{H} 1$ in transformer $\mathrm{T} 1$ and steel 27ZDKH85 in the T2 unit (the DHM-inductors of both these steels can be taken at [14] or in the current version of EMTP-ATP [15]).

The lengths of the legs, yokes, and lateral limbs of $\mathrm{T} 2$ are $3.340 \mathrm{~m}, 2.421 \mathrm{~m}$, and $6.257 \mathrm{~m}$ respectively, their cross-sections are $0.8309 \mathrm{~m}^{2}, 0.4959 \mathrm{~m}^{2}$, and $0.4155 \mathrm{~m}^{2}$. Transformer $\mathrm{T} 1$ has 11 percent less cross sections and, respectively, larger turn numbers.

The percentage short circuit reactances of $\mathrm{T} 2$ provided in [7] yield the following binary short-circuit inductances referred to the HV side: $L_{\mathrm{S} 12}=263.5 \mathrm{mH}, L_{\mathrm{S} 23}$ $=540.4 \mathrm{mH}$, and $L_{\mathrm{S} 13}=877.5 \mathrm{mH}$. The winding resistances $r_{1}, r_{2}$, and $r_{3}$ are brought outside the inductive part of the model. Their values in T2 are $0.34 \Omega, 28 \mathrm{~m} \Omega$, and $16 \mathrm{~m} \Omega$ respectively. Resistances of $\mathrm{T} 1$ are $30 \%$ greater. Resistances $R_{\text {inf }}=10^{9} \Omega$ make the MV windings effectively open-circuited and the delta LV windings unloaded, according to [7].

To match $L_{\mathrm{S} 12}, L_{\mathrm{S} 23}$, and $L_{\mathrm{S} 13}$, the conventional starconnected inductances $L_{12}, L_{23}$, and $L_{\mathrm{p}}$ are used in the model of fig. 3. The value of the negative inductance $L_{\mathrm{p}}$ is $\left(L_{\mathrm{S} 12}+L_{\mathrm{S} 23}-L_{\mathrm{S} 13}\right) / 2 \quad[4]$, then $L_{12}=L_{\mathrm{S} 12}-L_{\mathrm{p}}$, and $L_{23}=L_{\mathrm{S} 23}-L_{\mathrm{p}}$.

In the absence of winding design data, inductance $L_{01}$ of the innermost channel Leg-MV was related to the short-circuit inductance $L_{\mathrm{S} 12}$ of the next channel MV-HV. Following [3], the ratio $k_{01}=L_{01} / L_{\mathrm{S} 12}$ can be evaluated by the insulating clearances of these channels, which are assumed proportional to the voltages across the channels. Taking into account the zero potential of the core, $k_{01}=$ $V_{\mathrm{M}} /\left(V_{\mathrm{H}}-V_{\mathrm{M}}\right)=0.413$, which is rounded to 0.42 .

The role of inductance $L_{04}$ was explained in [4]. Since the modeled five-limb transformers have reinforced yokes $\left(\mathrm{A}_{\text {yoke }}=0.6 \mathrm{~A}_{\text {leg }}\right)$, the variation of $L_{04}$ in the range $\left[0, L_{\mathrm{S} 12}\right]$ does not affect the model behavior, and $L_{04}$ was set equal to $L_{\mathrm{S} 12}$.

So, the only fitting parameter of the model is the value of $L_{03}$. Similarly to $L_{01}$ and $L_{04}$, it is related to $L_{\mathrm{S} 12}$ by the ratio $k_{03}=L_{03} / L_{\mathrm{S} 12}$. In general, all three inductances $L_{03}$ can be chosen individually, but for simplicity, they are assumed to be the same. The iterative search of $L_{03}$ was resulted in $k_{03}=14$ for transformer T2 and $k_{03}=$ 10 for T1, which will be used in all calculations below.

\section{MODELING TECHNIQUE}

The initial stage of the modeling is the fit of the transformer models to the measured no-load losses of $\mathrm{T} 1$ $(172 \mathrm{~kW})$ and T2 $(100 \mathrm{~kW})$. As proposed in [5], the model fitting to these losses is carried out by choosing the coefficient $K_{\text {loss }}$ of the DHM. The reactive and hence the apparent power in the rated no-load regime can be fitted by changing the core air gaps $g$. We do not dwell on these details, because, as shall be shown below, the no-load losses do not practically influence the transformer behav- ior under large GICs.

As will be shown in the next section, it is important to take into account the positive $\left(Z_{1}\right)$ and zero-sequence $\left(Z_{0}\right)$ impedances of the power network. According to Fingrid evaluations at the time of the test [7], the per phase impedance $Z_{1}$ at $f_{1}=50 \mathrm{~Hz}$ is formed by $R_{1}=10.54 \Omega$ and $L_{1}=181.3 \mathrm{mH}$. The impedance $\mathrm{Z}_{0}$ was evaluated using the frequency content of the current in the earthling conductor of the equivalent network source in fig. 1. It was found by a Fourier analysis of the calculated earth current (current $i_{\text {earth }}$ in fig. 1) that the third $(150-\mathrm{Hz})$ harmonic distinctly dominates in its waveform. This is because, in the configuration considered, the current returning to the remote generator is the sum of currents in the neutrals of $\mathrm{T} 1$ and T2, and both of them are sums of three strongly asymmetrical (phase) currents shifted by 120 degrees that causes three positive and three negative peaks in their waveforms. This means that the network impedance $\mathrm{Z}_{0(3)}$ $=748.7 \exp \left(\mathrm{j} 66.3^{\circ}\right)=R_{0(3)}+j 2 \pi f_{3} L_{0(3)}$ calculated by Fingrid for $f_{3}=150 \mathrm{~Hz}$ should be used.

If the solver employed has a standard $\pi$-equivalent of the network, the values of $R_{1}, L_{1}, R_{0(3)}$, and $L_{0(3)}$ are entered directly into the window of this component. An alternative way of accounting for $\mathrm{Z}_{0}$ is the use of the network equivalent in fig. 4 in which the boxes T1 and T2 contain transformer model shown in fig. 3.

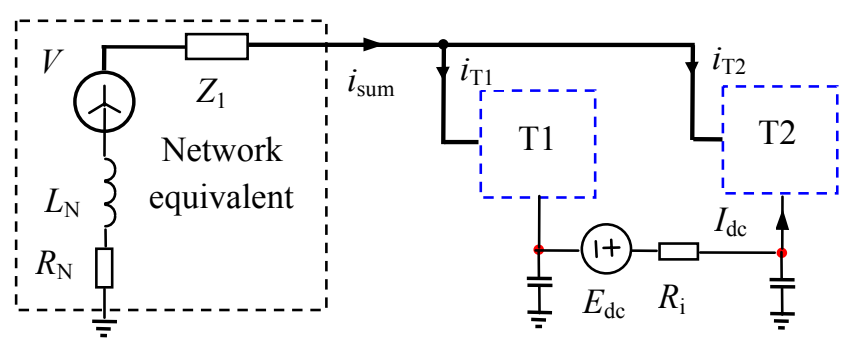

Figure 4. Model configuration employed.

Using the values $R_{0(3)}=300.7 \Omega, L_{0(3)}=727.5 \mathrm{mH}$, and the generic formula for ground-return impedance, $Z_{\mathrm{N}}=\left(Z_{0}-Z_{1}\right) / 3$ [16], [17] the following network parameters should be used in fig. 4: $R_{\mathrm{N}}=96.7 \Omega$ and $L_{\mathrm{N}}=182.1$ $\mathrm{mH}$. The elevated source voltage $(\mathrm{V}=416 \mathrm{kV})$ is to compensate for the voltage drops over the network and provide the voltage $(\approx 404 \mathrm{kV})$ observed across the modeled transformers at 200-A GIC. The value of the shunt capacitors $C$ has not been documented, but this is not an influencing parameter if $C>100 \mu \mathrm{F}$. The current $I_{\mathrm{dc}}$ is determined by the voltage $E_{\mathrm{dc}}$ of the generator $\mathrm{G}$, its internal resistance $R_{\mathrm{i}}$, and resistances $r_{11}$ and $r_{21}$ of the HV windings of T1 and T2: $I_{\mathrm{dc}}=E_{\mathrm{dc}} /\left(R_{\mathrm{i}}+r_{11} / 3+r_{21} / 3\right)$.

In all the simulations below, a three-phase ramped voltage of the network is initially used in the model to establish symmetrical flux densities in the legs of both the transformers. To observe dynamics of GIC events, it is supposed that the GIC considered is initiated by a step voltage of generator $\mathrm{G}$ in fig. 4 , which is switched on at $t$ $=2 \mathrm{~s}$. The following transient is characterized by a growth in the currents and the reactive power consumed by $\mathrm{T} 1$ and T2. The calculated rms values of the currents in phas- 
es $\mathrm{B}$ and $\mathrm{C}$ of $\mathrm{T} 2$ as well as the reactive power $\mathrm{Q}_{2}$ consumed by this transformer are shown in fig. 5. In steady state, the rms currents in fig. 5 reach 108 and $124 \mathrm{~A}$, which are close to the measured values of 110 and $125 \mathrm{~A}$ (for phases $\mathrm{B}$ and $\mathrm{C}$ respectively). The steady state reactive power $\mathrm{Q}_{2}$ is 53.1 Mvar that also is close to the measured 55 Mvar.

The waveforms of all three phase currents in the steady state (calculated in the presence of 200-A DC current) are shown in fig. 6. They agree quite well with the measured currents in fig. 7. The same good agreement was obtained for the current waveforms in the network (three-phase currents $i_{\text {sum }}$ in fig. 4) so we do not show them in the paper.

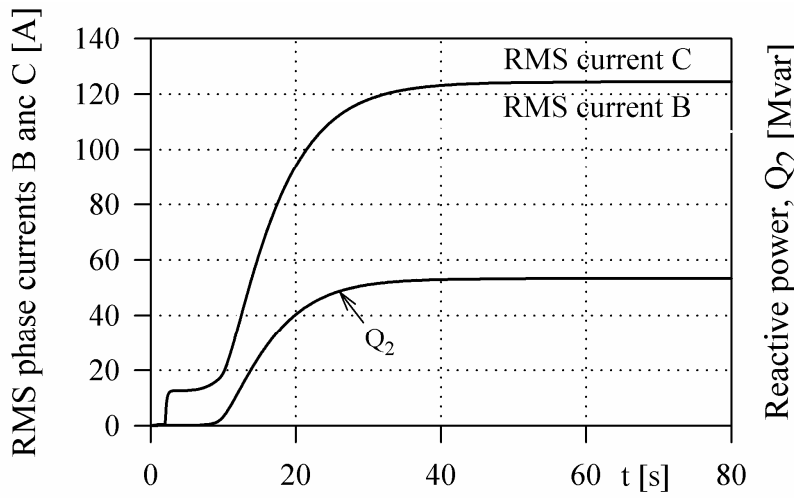

Figure 5. Calculated RMS currents in phases B and C of transformer $\mathrm{T} 2$ and the reactive power $\mathrm{Q}_{2}$ consumed by $\mathrm{T} 2$ during the transient.

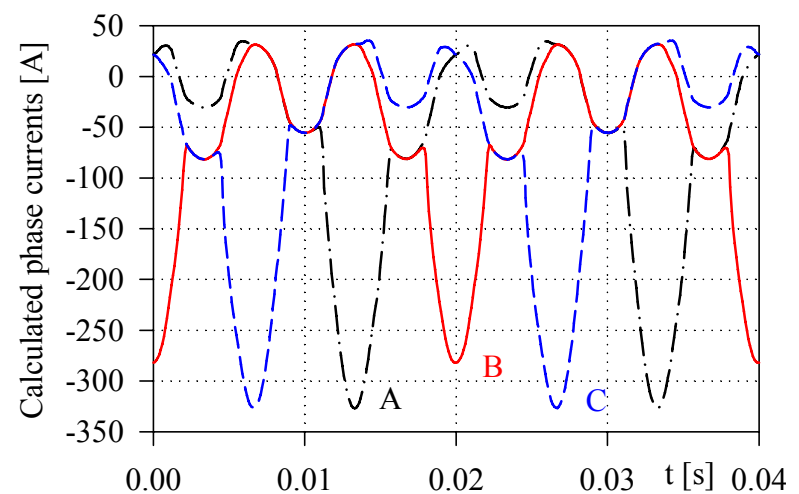

Figure 6. Calculated phase currents in T2.

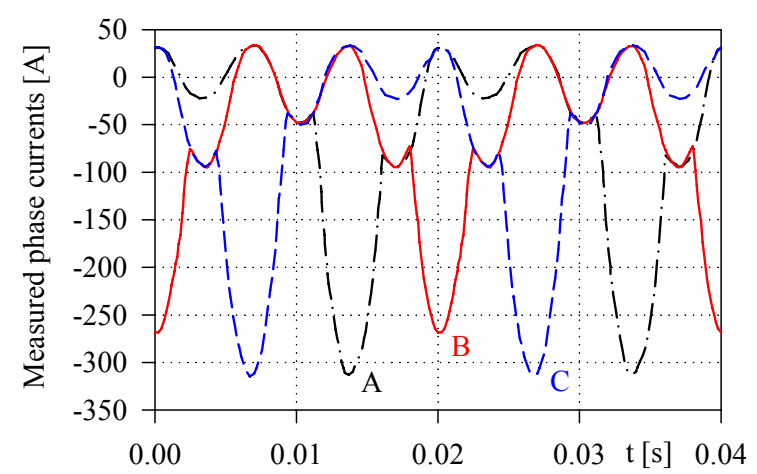

Figure 7. Measured phase currents in T2.
Figs. 8, 9, and 10 show calculated flux densities in the core leg, yoke, and the end limbs respectively.

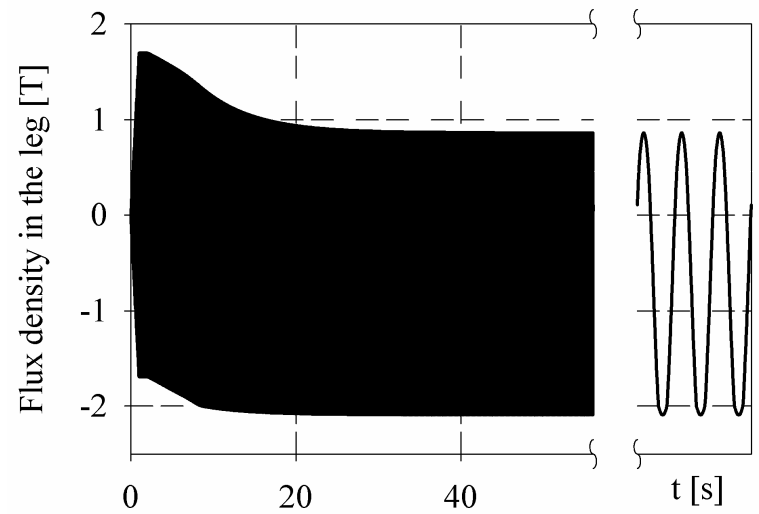

Figure 8. Flux density in the leg A.

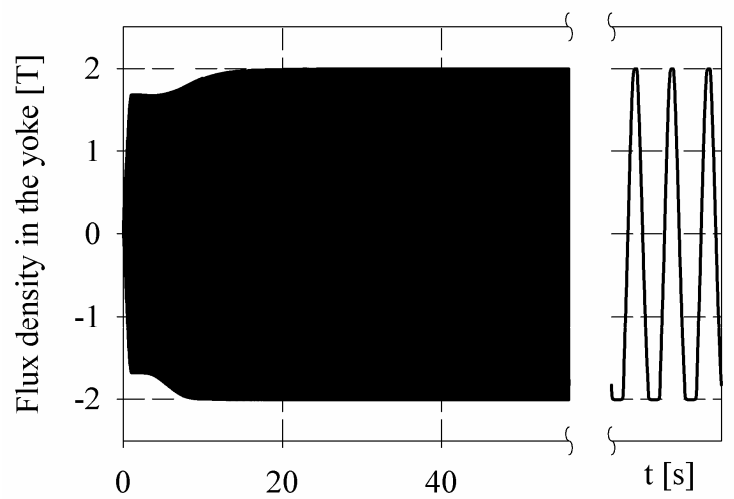

Figure 9. Flux density in the yoke AB.
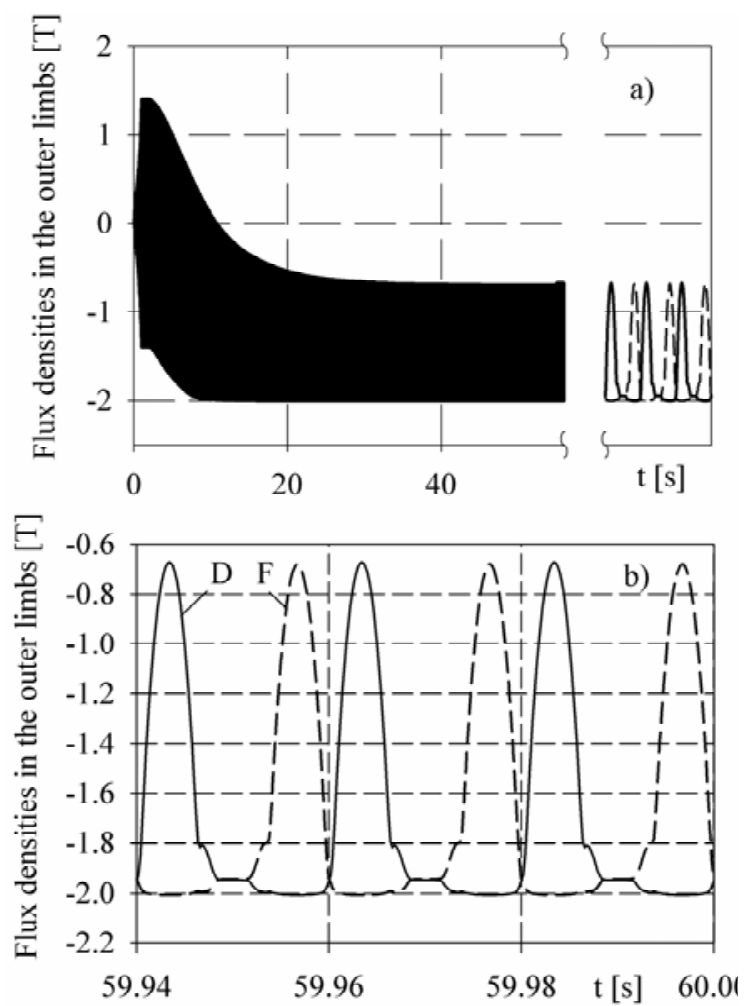

Figure 10. Flux densities in the outer limbs D and F during (a) transient and (b) steady state. 
These demonstrate their different waveforms during the transient and steady state. As can be seen in fig. 10(b), the end limbs D and F are saturated non-simultaneously, and there is no point of time at which both $B_{\mathrm{D}}$ and $B_{\mathrm{F}}$ drop below $-2 \mathrm{~T}$. This shows that the zero-sequence flux closes mainly within the core and explains why there is no need for a detailed tank model when the five-leg transformer is considered as network element.

\section{V.UNREALISTIC MODELING IN [8]}

It should be recalled at this point that the influence of the network parameters (impedances $\mathrm{Z}_{1}$ and $\mathrm{Z}_{0}$ ) was not immediately evident, and considerable unsuccessful efforts were made to obtain the realistic waveforms in fig. 6 using the initial model configuration in fig. 1. The power network is represented in fig. 1 by an ideal voltage source, which was also used in [8]. The current waveforms in transformer T2 calculated for the initial configuration are shown in fig. 11 .

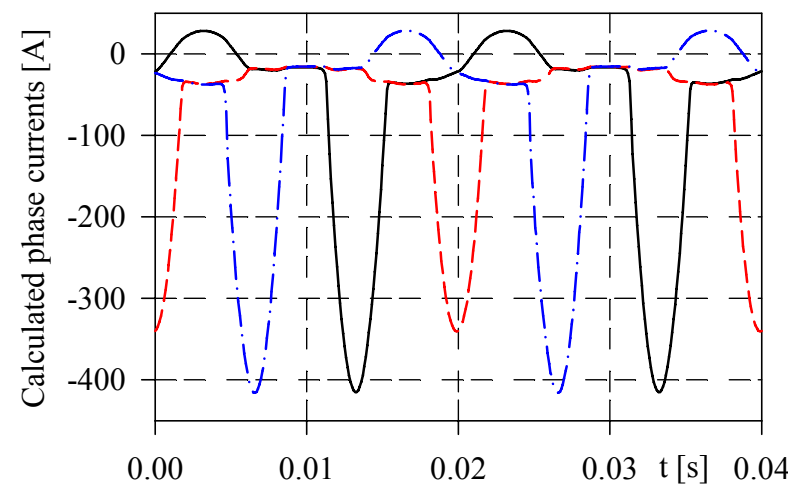

Figure 11. Phase currents in $\mathrm{T} 2$ calculated with the ideal network.

The currents in fig. 11 are markedly different from the measured currents in fig. 7. All our attempts to improve the waveforms in fig. 11 by changing the structure and parameters of the transformer model were in vain, pointing out that the reason lies outside the transformer representation.

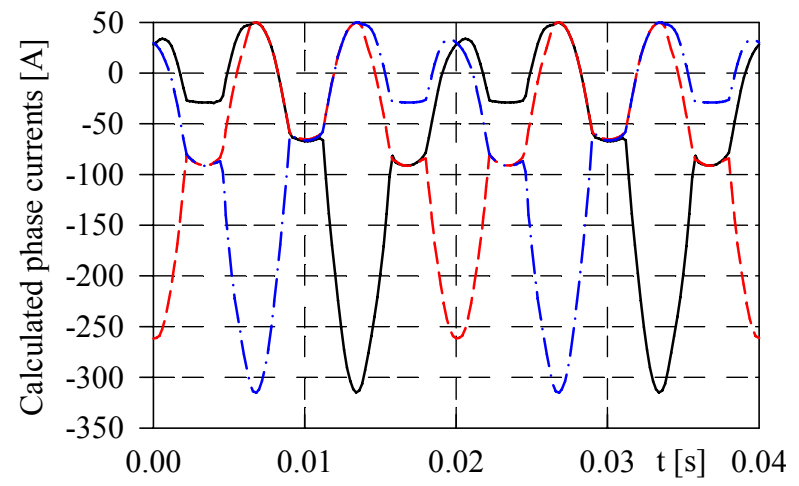

Figure 12. Phase currents in $\mathrm{T} 2$ calculated with ideal network and in the absence of earthing capacitors used in the measurements.

A pragmatic measure to circumvent this difficulty was observed by one of the co-authors (D.B.) and then used independently in [8]. This artificial measure is to substitute capacitors $C$ in the scheme of fig. 1 with large resistances. The current waveforms calculated in the $a b-$ sence of capacitors $C$ and for the idealized $400-\mathrm{kV}$ network are shown in fig. 12.

The currents in fig. 12 and similar waveforms in [8] outwardly resemble the measured currents in fig. 7 , but we should stress again that they were obtained using the model configuration different from that in the actual test [7] and hence cannot validate the "advanced" model [9], [10].

It should be noted that plausible currents in the HV windings of transformer $\mathrm{T} 2$ can also be simulated in the model configuration in fig. 13, which contains only one this transformer. In accordance with [8], an ideal voltage source $V$ is used in this configuration $\left(Z_{1}=0\right)$, and there are no grounding capacitances $C$. The latter simplification means that the internal inductance $L_{\mathrm{i}}$ of the welding generator $\mathrm{G}$ can be included in series with its resistance $R_{\mathrm{i}}$. To obtain the needed current $I_{\mathrm{dc}}$ in the neutral, the e.m.f. $E_{\mathrm{dc}}$ in fig. 13 is set equal to $\left(r_{11} / 3+R_{\mathrm{i}}\right) I_{\mathrm{dc}}$.

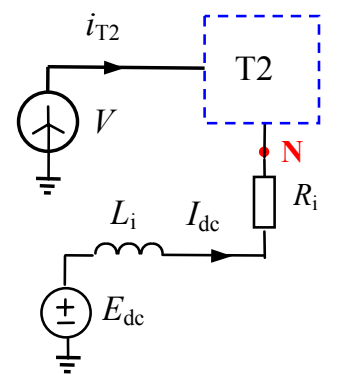

Figure 13. Model configuration with one transformer T2.

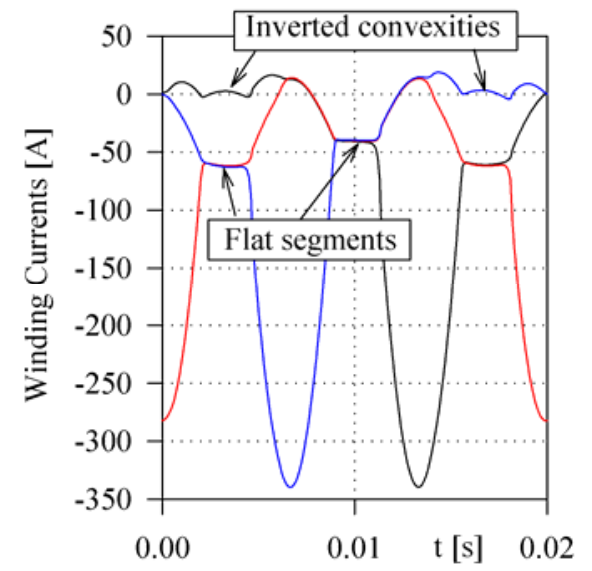

Figure 14. Phase currents of $T 2$ calculated with the model configuration in fig. 13.

Steady-state currents in T2 calculated at V $=400 \mathrm{kV}$ and $L_{\mathrm{i}}=400 \mathrm{mH}$ are shown in fig. 14. Although, in comparison to the waveforms in fig. 11, they are closer to the measured currents in fig. 7, these curves have flat segments and "inverted convexities", which are absent in the measured waveforms. The presence of similar segments 
and convexities in the currents shown in [8, fig. 7] allows one to suppose that the analysis in [8] could be carried out for a model configuration similar to that in fig. 13, but not for the two-transformer arrangement in fig. 1.

Although the model configuration in fig. 13 does not reflect the actual test conditions in [7] where the impact of $L_{\mathrm{i}}$ is cancelled by capacitors $\mathrm{C}$, the favorable influence of $L_{\mathrm{i}}$ in fig. 13 should be discussed further. It can be seen that all the elements of the circuit in fig. 13 are connected in series, so inductance $L_{\mathrm{i}}$ can be moved into the grounding conductor of the voltage source. In this case, inductance $L_{\mathrm{i}}$ takes the place and role of inductance $L_{\mathrm{N}}$ in the circuit of fig. 4. This explains the need for accounting for the zero-sequence impedance of the network implemented in the model configuration in fig. 4.

In concluding this section, we mention a separate study conducted to estimate the influence of hysteretic properties of the core material. With this purpose, each of the DHM-inductors in the model of fig. 3 was replaced by a lossless non-hysteretic inductance. The flux-current relationships of these inductances (different for legs and yokes) were obtained from the "middle" (anhysteretic) curves of the steel employed. It was found by numerical experiments that all the results calculated with nonhysteresis and hysteresis models practically almost coincide. It is remarkable that the coincidence was also obtained in portraying the "hysteresis loop" shown in fig. 10 of [7]. This shows that this loop is not caused by hysteresis properties of the core, but is a kind of Lissajous figure occurred due to the phase shift between the flux density of the leg and corresponding terminal current.

When the modeling of GIC events had been completed, it turned out that the model also predicts accurately the zero sequence impedances of the transformers measured from both HV and MV sides (they are $40.1 \%$ and $65.2 \%$ respectively).

\section{CONCLUSION}

In addition to accuracy, an important feature of the transformer transient model intended for network studies is its simplicity and ease of implementation. It is always desirable to understand the capabilities of the models developed within the well-established framework, before proposing new, often unnecessary complicated tools. With this idea in mind, we have considered the capabilities of the conventional topological model of five-leg transformer in simulating transformer behavior at high flux densities in the core legs and yokes. In fitting the model, we used field test results from two 400 MVA transformers with 200-A DC currents entering their neutrals. It was found that accurate modeling of the test in [7] requires the network impedances to be taken into account, as well as the actual back-to-back connection of the transformers considered.

It was found that the presence of the tank can be effectively accounted for by linear inductances representing the off-core fluxes from yoke to yoke. This finding is not unexpected because the same conclusion was made in studying inrush current events in a three-limb Yyn transformer [5] in which an accurate tank model was anticipated due to the core design and higher flux densities in the core.

Having started with hysteretic transformer model, we have ended up with a simplified non-hysteretic model, which reproduces transformer currents and reactive power with the same good accuracy. This means that in its anhysteretic form, the model can be implemented in any computing environment, and the data provided in the paper is sufficient to repeat the calculated waveforms with the use of any circuit simulator.

The model is mainly a tool for power system studies, in which the application of finite-element models is inappropriate because of the computational cost and the presence of several transformers in the studied network.

\section{REFERENCES}

[1]. Arturi, C. M. (1991). Transient simulation of a three phase five limb step-up transformer following an outof-phase synchronization. IEEE Trans. Power Delivery, 6, 1, 196 - 207. DOI: $10.1109 / 61.103738$.

[2]. Chen, X., Venkata, S.S. (1997). A three-phase threewinding core-type transformer model for lowfrequency transient studies. IEEE Trans. Power Delivery, 12, 2, 775 - 782. DOI: 08858977/97/\$10.00.

[3]. Mork, B. A., Gonzalez, F., Ishchenko, D., Stuehm, D. L., Mitra J. (2007). Hybrid transformer model for transient simulation - Part I: Development and parameters. IEEE Trans. Power Delivery, 22, 1, 248 255. DOI: 10.1109/TPWRD.2006.883000.

[4]. Zirka, S. E., Moroz, Y. I., Arturi, C. M. (2014). Accounting for the influence of the tank walls in the zero-sequence topological model of a three-phase, three-limb transformer. IEEE Trans. Power Delivery, $29, \quad 5, \quad 2172-2179 . \quad$ DOI: $10.1109 /$ TPWRD.2014.2307117.

[5]. Zirka, S. E., Moroz, Y.I., Høidalen, H. Kr., Lotfi, A., Chiesa, N., Arturi, C. M. (2017). Practical experience in using a topological model of a core-type threephase transformer - No-load and inrush conditions. IEEE Trans. Power Delivery, 32, 4, 2081-2090. DOI: 10.1109/TPWRD. 2016.2618900.

[6]. Tikhovod, S.M. (2014). Modelirovanie perehodnyh processov $\mathrm{v}$ transformatorah na osnove magnitojelektricheskih shem zameshhenija. [Modeling transformer transients using magnitoelectric equivalent schemes]. Elektrotehnika i elektroenergetika, 2, 59-68, (in Russian).

[7]. Lahtinen, M., Elovaara, J. (2002). GIC occurrences and GIC test for $400 \mathrm{kV}$ system transformer. IEEE Trans. Power Delivery, 17, 2, 555-561. DOI: 08858977(02)02750-4.

[8]. Rezaei-Zare, A. Marti, L., Narang, A., Yan, A. (2016). Analysis of three-phase transformer response due to GIC using an advanced duality-based model. IEEE Trans. Power Delivery, 31, 5, 2342-2350. 
DOI: 10.1109/TPWRD. 2015.2505499.

[9]. Rezaei-Zare, A. (2015). Enhanced transformer model for low- and mid-frequency transients-Part I: Model development. IEEE Trans. Power Delivery, 30, 1, 307-315. DOI: 10.1109/TPWRD.2014.2347930.

[10]. Rezaei-Zare, A. (2015). Enhanced transformer model for low- and mid-frequency transients-Part II: Validation and simulation results. IEEE Trans. Power Delivery, 30, 1, 316-325. DOI: 10.1109/TPWRD.2014.2347934.

[11]. Lambert, M., Mahseredjian, J. (2013) Electromagnetic transient type transformer models for geomagnetically-induced current (GIC) studies. EPRI Report 3002000832.

[12]. Zirka, S. E., Moroz, Y. I., Rahimpour, E. (2017). Towards a transformer transient model as a lumpeddistributed parameter system. Compel, 36, 3, 741750. DOI: 10.1108/COMPEL-09-2016-0389.
G., Høidalen, H. Kr. (2015). Implementation of inverse hysteresis model into EMTP - Part II: Dynamic model. IEEE Trans. Power Delivery, 30, 5, 2233-2241. DOI: 10.1109/TPWRD. 2015.2416199.

[14]. Moroz, Y. I., Zirka, S. E. (2014). Inverse models of magnetic hysteresis, [Online]. Available: https://sites.google.com/site/inverse-hysteresismodel.

[15]. Alternative Transients Program, ATP-EMTP, (2016). [Online]. Available: http://www.eeug.org.

[16]. Tleis, N. D. (2008). Power systems modelling and fault analysis: Theory and practice. New York: Newnes/Elsevier, 625.

[17]. Evdokunin, G. A. (2016). Jelektricheskie sistemy i seti [Electrical systems and networks]. Saint Petersburg: Rodnaya Ladoga, 384, (in Russian).

Manuscript received 01.10.2017

[13]. Zirka, S. E., Moroz, Y. I., Chiesa, N., Harrison, R.

\section{ТОПОЛОГІЧНІ МОДЕЛІ ТРИФАЗНОГО П'ЯТИСТРИЖНЕВОГО TРАНСФОРМАТОРА}

3IPKA C. C.

MOPO3 Ю. I.

д-р техн. наук, професор, професор кафедри систем автоматизованого управління Дніпровського національного університету, Дніпро, Україна, e-mail: zirka@email.dp.ua;

АРТУРІ Ц. М. канд. техн. наук, доцент, доцент кафедри систем автоматизованого управління Дніпровського національного університету, Дніпро, Україна, e-mail: yuriy_moroz@i.ua; професор факультету електроніки, інформації і біоінженерії Міланського Політехнічного інституту, Мілан, Італія, e-mail: cesaremario.arturi@polimi.it;

БОННМАН Д. д-р техн. наук, АВВ, Бад-Гоннеф, Німеччина, e-mail: dietrich.bonmann@de.abb.com.

Мета роботи. Показати, що на основі топологічних моделей трифазного п'ятистрижневого трансформатора можливо коректно відтворювати його роботу в режимах великих індукиій в осерді. В якості практично важливого прикладу, аналізується часовий відгук трансформатора на дію геомагнітно-індукованих струмів (ГІТ). Результати моделювання порівнюються з результатами натурного експерименту.

Методи дослідження. Магнітна модель трансформатора, щяо враховує геометрію осердя і обмоток, перетворюється в дуальну електричну схему заміщення, перехідний процес в якій розраховується в середовищі ЕМТР-АТР. Отримані результати демонструють необхідність урахування опорів прямої і нульової послідовності енергосистеми.

Отримані результати. Розроблено адекватну, просту і надійну модель n'ятистрижневого трансформатора. Встановлено, що присутність бака трансформатора може бути врахована за допомогою лінійних індуктивностей, що представляють шиляхи магнітних потоків поза осердям (потоків від ярма до ярма). Точність представленого моделювання процесів в трансформаторі в присутності ГІТ перевищує точність відомих моделей трифазних п'ятистрижневих трансформаторів. Адекватність моделі підтверджується близькістю прогнозованих діючих значень і кривих фазних струмів, а також споживаної реактивної потужності, до відповідних величин, виміряних в експерименті, проведеному на двох 400 МВА трансформаторах, які були під'єднані паралельно до енергосистеми напругою 410 кB і послідовно відносно джерела постійної напруги.

Наукова новизна. Розроблено спрощену безгістерезисну модель n'ятистрижсевого трансформатора, яка відтворює поведінку трансформатора з такою ж високою точністю, що і гістерезисна модель, яка відрізняється тем, що вибір безгістерезисної моделі є науково обтрунтованим.

Практична цінність. Практична цінність $і$ значимість статті обумовлено тим, щзо запропонована модель трансформатора являе собою простий $і$ надійний інструмент для дослідження електричних мереж. Стаття застерігає від використання надмірно ускладнених моделей, параметри яких не можуть бути визначені в експерименті або знайдені шляхом розрахунків.

Ключові слова: п'ятистрижневий трансформатор, топологічні моделі, перехідний режим, магнітні потоки поза осердям, форми струмів, реактивна потужність, експериментальна перевірка, послідовнопаралельне включення. 


\section{ТОПОЛОГИЧЕСКИЕ МОДЕЛИ ТРЕХФАЗНОГО ПЯТИСТЕРЖНЕВОГО ТРАНСФОРМАТОРА}

ЗИРКА С. Е.

д-р техн. наук, профессор, профессор кафедры систем автоматизированного управления Днепровского национального университета, Днепро, Украина, e-mail: zirka@email.dp.ua;

MOРОЗ Ю. И. канд. техн. наук, доцент, доцент кафедры систем автоматизированного управления Днепровского национального университета, Днепро, Украина, e-mail: yuriy_moroz@i.ua;

АРТУРИ Ц. М. профессор факультета элэктроники, информации и биоинженерии Миланского Политехнического института, Милан, Италия, e-mail: cesaremario.arturi@polimi.it;

БОННМАН Д. д-р техн. наук, АВВ, Бад-Гоннеф, Германия, e-mail: dietrich.bonmann@de.abb.com.

Цель работы. Показать, что на основе топологических моделей трехфазного пятистержневого трансформатора возможно корректно воспроизводить его работу в режимах больших индукций в сердечнике. В качестве практически важного примера, анализируется временной отклик трансформатора на воздействие геомагнитно-индуцированных токов (ГИТ). Результаты моделирования сравниваются с результатами натурного эксперимента.

Методы исследования. Магнитная модель трансформатора, учитывающая геометрию сердечника и обмоток, преобразуется в дуальную электрическую схему замещения, переходный процесс в который рассчитывается в среде ЕМТР-АТР. Полученные результаты демонстрируют необходимость учета сопротивлений прямой и нулевой последовательности энергосистемы.

Полученные результаты. Разработана адекватная простая и надежная модель пятистержневого трансформатора. Установлено, что присутствие бака трансформатора может быть учтено посредством линейных индуктивностей, представляющих пути магнитных потоков вне сердечника (потоков от ярма к ярму). Точность представленного моделирования прочессов в трансформаторе при наличии ГИТ превышает точность известных моделей трехфазных пятистержневых трансформаторов. Адекватность модели подтверждается близостью предсказанных действующих значений и кривых фазных токов, а также потребляемой реактивной мощности, к соответствующим величинам, измененным в эксперименте, проведенном на двух 400 МВА трансформаторах, которые соединены параллельно к энергосистеме напряжением 410 кВ и последовательно по отночению к источнику постоянного напряжения.

Научная новизна. Разработана упрощенная безгистерезисная модель пятистержневого трансформатора, которая воспроизводит поведение трансформатора с той же высокой точностью, что и гистерезисная модель, отличающаяся тем, что выбор безгистерезисной модели научно обоснован.

Практическая ченность. Практическая ценность и значение статьи обусловлено тем, что предложенная модель трансформатора является простым и надежным инструментом для исследования электрических сетей. Статья предостерегает от использования излишне усложненных моделей, параметры которых не могут быть определены в эксперименте или посредством вычислений.

Ключевые слова: пятистержневой трансформатор, топологические модели, переходный режим, магнитные потоки вне сердечника, формы токов, реактивная мощность, экспериментальная проверка, последовательно-параллельное включение трансформаторов. 